\title{
New host of Anastrepha parishi Stone (Diptera: Tephritidae) reported in Brazil
}

\author{
Adaime, R. ${ }^{a *}$, Marsaro Júnior, AL. ${ }^{b}$, Souza-Filho, MF. ${ }^{c}$, Chagas, EA. ${ }^{d}$ and Lima, CGB. ${ }^{d}$ \\ ${ }^{a}$ Embrapa Amapá, Rod. JK, Km 5, 2600, CEP 68903-419, Macapá, AP, Brazil \\ 'Embrapa Trigo, Rod. BR 285, Km 294, CEP 99001-970, Passo Fundo, RS, Brazil \\ 'Instituto Biológico, CP 70, CEP 13012-970, Campinas, SP, Brazil \\ ${ }^{d}$ Embrapa Roraima, Rod. BR-174, Km 8, Distrito Industrial, CEP 69301-970, Boa Vista, RR, Brazil \\ *e-mail: adaime@cpafap.embrapa.br
}

Received July 14, 2011 - Accepted July 14, 2011 - Distributed February 29, 2012

The description of Anastrepha parishi Stone, 1942 was based on specimens collected in Guyana, but the species is also present in Costa Rica (Gonzáles et al., 1988), Suriname, Venezuela (Caraballo, 1981) and, recently, in Brazil (Jesus et al., 2008). Its only known hosts are Psidium guajava (Myrtaceae) in Venezuela (Caraballo, 1981) and Oenocarpus bacaba (Arecaceae) in Brazil (Jesus et al., 2008).

On March 30, 2010, during a fruit sampling procedure aiming to collect fruit flies in the vicinity of Urubu River, in the Serra da Lua region within the municipality of Boa Vista $\left(02^{\circ} 21^{\prime} \mathrm{N}\right.$ and $\left.60^{\circ} 02^{\prime} \mathrm{W}\right)$, state of Roraima, a total of 17 fruits (117.69 g) of Myrciaria dubia (Kunth) McVaugh (Myrtaceae) were collected. Myrciaria dubia is commonly known as camu-camu, caçari or araçá-de-água.

The camu-camu is native to a region extending from the Northwest Brazilian Amazon to Peru, with distribution limited to flooded areas or margins of rivers and streams. The species is also found in Colombia and Venezuela. It is an evergreen shrub, up to $4 \mathrm{~m}$ tall, in rare cases reaching $8-10 \mathrm{~m}$ tall. The fruit is a spherical berry $(2-2.5 \mathrm{~cm}$ in diameter), with a thin, smooth, glossy skin of a red colour that becomes purplish-black at the end of the ripening period. The pulp is succulent and very acidic, and is consumed in natura or in processed form (juices, ice creams, wines, liqueurs, jams, etc.). However, the importance of the camucamu lies in the great economic potential offered by its main attribute, namely the high content of vitamin $\mathrm{C}$ in its pulp, which is much higher than the amount found in acerola and other fruits (Cavalcante, 1996; Siqueira, 1998; Donadio et al., 2002; Lorenzi et al., 2006).

From the fruits of $M$. dubia, we obtained two puparia (infestation rate: 0.1 puparium/fruit and 17.0 puparia/ $\mathrm{kg}$ ), from which two specimens of Anastrepha emerged ( 1 female and 1 male). The female was identified as Anastrepha parishi Stone (voucher specimen deposited in the Instituto Biológico collection).

Myrciaria dubia is a newly reported host of A. parishi in Brazil. The species has already been reported as a host of Anastrepha obliqua (Macquart) in the state of Amazonas
(Silva, 1993). This is also the first report of A. parishi in the state of Roraima, which previously had been collected only in the state of Amapá (Jesus et al., 2008). Anastrepha parishi therefore deserves further study, as this is the third report of a host (two plant families) of the species.

Acknowledgements - To the CNPq for the Research Productivity Fellowships granted to the first and fourth authors and for financial assistance for project 550963/2010-3 (Rede Bionorte). To CAPES for the Post-Doctoral Fellowship (PNPD) granted to the fifth author.

\section{References}

CARABALLO, CJ., 1981. Las moscas de frutas del genero Anastrepha Schiner, 1868 (Diptera, Tephritidae) de Venezuela. Maracay: Universidad Central de Venezuela. 210 p. Tesis de Maestria.

CAVALCANTE, PB., 1996. Frutas comestíveis da Amazônia. 6nd ed. Belém: CNPq/Museu Paraense Emílio Goeldi. 279 p.

DONADIO, LC., MÔRO, FV. and SERVIDONE, AA., 2002. Frutas brasileiras. Jaboticabal: Novos Talentos. 288 p.

GONZÁLES, IM., LEZANA, HJ. and JIRÓN, LF., 1988. Anastrepha fruit flies in Costa Rica: three new records. Revista de Biologia Tropical, v. 36, p. 333-335.

JESUS, CR., OLIVEIRA, MN., SOUZA-FILHO, MF., SILVA, RA. and ZUCCHI, RA., 2008. First record of Anastrepha parishi Stone (Diptera, Tephritidae) and its host in Brazil. Revista Brasileira de Entomologia, v. 52, p. 135-136. http://dx.doi.org/10.1590/ S0085-56262008000100023

LORENZI, H., BACHER, L., LACERDA, M. and SARTORI, S., 2006. Frutas brasileiras e exóticas cultivadas: de consumo in natura. São Paulo: Instituto Plantarum de Estudos da Flora. 672 p.

SILVA, NM., 1993. Levantamento e análise faunística de moscas-das-frutas (Diptera: Tephritidae) em quatro locais do Estado do Amazonas. Piracicaba: Escola Superior de Agricultura "Luiz de Queiroz", Universidade de São Paulo. 152 p. Tese de Doutorado em Ciências.

SIQUEIRA, GCL., (Coord.), 1998. Сати-сати: produtos potenciais da Amazônia. Brasília: MMA-SUFRAMA. 31p. 
